\title{
Prey selectivity by juvenile Atlantic cod Gadus morhua in three coastal habitat types
}

\author{
Peter Ljungberg*, P. Anders Nilsson, Anders Persson \\ Department of Biology, Aquatic Ecology, Ecology Building, Lund University, 22362 Lund, Sweden
}

\begin{abstract}
Coastal habitats are heavily subjected to eutrophication and commercial fisheries, and such alterations can affect organism interaction strengths and potentially influence trophic dynamics. A key species inhabiting coastal environments in temperate waters is the Atlantic cod Gadus morhua, which utilises coastal areas for food and shelter. We used an experimental mechanistic approach to assay prey selectivity by juvenile cod when foraging on grass shrimp Palaemon elegans and brown shrimp Crangon crangon, under light and dark conditions, in 3 of the most abundant habitat types in temperate coastal environments - sand, eelgrass (artificial vegetation mimicking Zostera marina), and bladderwrack Fucus vesiculosus. Using functional response relationships from single-prey experiments, we calculated the energetically best foraging strategy for cod in the 3 habitats, i.e. feeding selectively on either of the shrimp species or on a combination of both. These predictions were tested in experiments where the cod predator was offered both prey species. Cod selected both prey species in accordance with our predictions in eelgrass and in bladderwrack under light conditions, but a lower than predicted consumption of grass shrimp was found in sand and in bladderwrack under dark conditions. Cod decreasingly selected grass shrimp with increasing habitat complexity, i.e. the highest selectivity was in sand and the lowest selectivity was in bladderwrack. As the 2 shrimp species have different trophic roles, cod selective predation may have effects on lower trophic levels. We provide a quantitative prediction of cod selective predation in habitat types that undergo degradation, and suggest that such predation can influence the trophic consequences from environmental change.
\end{abstract}

KEY WORDS: Prey choice - Functional response - Trophic cascade $\cdot$ Seagrass $\cdot$ Macroalgae · Atlantic cod $\cdot$ Gadus morhua $\cdot$ Shrimp

\section{INTRODUCTION}

Coastal marine ecosystems worldwide are subject to heavy disturbances inflicted by eutrophication and extensive commercial fishing (Jackson et al. 2001, Halpern et al. 2008). Impacts originate from both natural and anthropogenic sources and may have farreaching trophic effects, because they can alter community composition and interactions (Daskalov et al. 2007, Eriksson et al. 2009, Richardson et al. 2009). Coastal zones are among the most vulnerable marine environments and these highly productive and often vegetated areas provide both food resources and refuge from predation for numerous aquatic species (Petersen 1918, Gibson 1994, Anderson 2001, Beck et al. 2001). Eutrophication of coastal zones can impair depth distribution and increase fragmentation of macrovegetation (i.e. patchiness) (Vogt \& Schramm 1991, Short \& Wyllie-Echeverria 1996, Baden et al. 2003). Along with ecosystem shifts towards a higher number of unvegetated areas (Rönnbäck et al. 2007), eutrophication alters the structure of coastal communities by creating conditions that favour filamentous algae over macrovegetation (Vogt \& Schramm 1991, Orth et al. 2006). This process creates a negative feedback loop leading to further loss of macrovegeta- 
tion, enhanced by phytoplankton blooms, increased turbidity, reduced light availability, and oxygen depletion (Cloern 2001).

While eutrophication predominantly affects juvenile fish and the lower trophic levels of the food web (Carr 1989), commercial fishing often targets top predatory species (Pauly et al. 2002, Heck \& Valentine 2007). Loss of larger predatory fish may relieve lower trophic levels, mainly smaller fish and mesopredators, from predation pressure (Jackson et al. 2001, Frank et al. 2005), and these effects cascade down to primary producers (Osterblom et al. 2007, Casini et al. 2009). In a recent study, Baden et al. (2010) suggested that intermediate predators such as large crustaceans and gobies are regulators of the mesograzer community, e.g. isopods and amphipods. Thus, knowledge about the performance of predators in regulating mesopredators in different environments is fundamental for understanding the combined effects of eutrophication and commercial fishing on coastal trophic dynamics. Furthermore, mesopredators can differ in habitat and/or food preferences, with potential consequences for the effects of predation in these systems. Knowledge of prey consumption and selectivity by predators in different habitat types is therefore crucial for understanding the overall effects of predation in coastal food webs. The present aim is to address these issues by quantifying prey selectivity in Atlantic cod Gadus morhua, a temperate fish species heavily exploited by commercial fisheries (Hutchings \& Myers 1994, Jackson et al. 2001, Frank et al. 2005), on intermediate predators occupying different coastal habitats.

The trophic effect of a top predator such as Atlantic cod will depend on where, when, and on what it forages. Optimal foraging theory offers a framework for distilling the mechanisms that generate certain foraging patterns. Typically, the best strategy will depend on the availability of different prey types, with predators being specialist foragers in richer environments and generalist foragers in poorer environments (Stephens \& Krebs 1986). In a varying or changing environment, a forager moving from poorer to richer conditions should apply an everexpanding specialist strategy, sequentially dropping prey types and feeding grounds that are of low profitability (Heller 1980, Brown \& Mitchell 1989). The availability of prey to a predator depends on the density of prey and prey accessibility, i.e. the relationship between the ability of the predator to successfully find and capture prey, and the ability of the prey to avoid being caught or consumed (Savino \& Stein 1982, Orth et al. 1984, 2006). Prey accessibility, in turn, is strongly dependent on habitat characteristics that affect visual range and predator manoeuvrability, such as light regime and structural complexity (Diehl 1988, Gotceitas \& Colgan 1989). These characteristics typically vary over time and space, and the predator's optimal strategy may vary accordingly. Hence, the mechanisms generating different foraging strategies need to be quantified to understand the effects predators may have on lower trophic levels in different habitats.

Juvenile cod are strongly associated with coastal environments, where they utilise a wide range of habitat types, including macroalgae (Keats et al. 1987, Borg et al. 1997), cobble/rock (Gotceitas et al. 1995, Tupper \& Boutilier 1995, Cote et al. 2001), sand (Borg et al. 1997) and eelgrass (Gotceitas et al. 1997, Laurel et al. 2003), and commonly perform diel migrations between the different habitats (Pihl \& Rosenberg 1982). Juvenile cod are major predators on invertebrate fauna (Pihl 1982, Smith et al. 2007), and have the potential to regulate lower trophic levels in coastal environments (Moksnes et al. 2008).

Grass shrimp Palaemon elegans and brown shrimp Crangon crangon are 2 mesopredators frequently found in the diet of juvenile Atlantic cod (Pihl 1982, Isaksson et al. 1994). They are of comparable size but differ in trophic positions and in habitat preferences (Baden \& Pihl 1984, Jephson et al. 2008). Although some habitat-choice overlap occurs, grass shrimp mainly inhabit vegetation (Berglund 1980), whereas brown shrimp predominantly associate with sandy habitats (Pihl \& Rosenberg 1982). The grass shrimp is a diurnal omnivore that feeds primarily on smaller crustaceans (Baden \& Pihl 1984, Jephson et al. 2008). It is a major predator on mesograzers in eelgrass beds and is a link between the decrease in predatory fish densities and the increase of filamentous algae (Persson et al. 2008, Baden et al. 2012). The brown shrimp, on the other hand, is a nocturnal benthic carnivore, affecting the infaunal community (Kuipers \& Dapper 1981, Baden \& Pihl 1984). Both shrimp species should generate comparable energetic returns because of their similar sizes. However, because the shrimp species differ in food preferences and thereby trophic characteristics, the relative predation rates on them by cod could be associated with different trophic consequences.

In the present study we used an existing dataset (Persson et al. 2012) of functional responses of cod when foraging separately on grass shrimp and brown shrimp in 3 habitat types: sand, artificial eelgrass, and bladderwrack Fucus vesiculosus, to predict for- 
aging strategies when both prey types were available. We experimentally evaluated cod selectivity between the 2 prey species in the 3 habitat types and compared our results with the predictions. Our experiments were performed under 2 light regimes because the 2 shrimp species differ in diel activity patterns. We hypothesised that cod should select prey so as to maximise energy intake rates. This selectivity should be habitat dependent, as prey accessibility should vary between habitats. Furthermore, we predicted that cod selectivity for grass shrimp should decrease under dark conditions, as brown shrimp would be more active in darkness. Finally, we related the experimentally revealed foraging strategies to field observations of prey densities and examined the potential role that cod prey selectivity may have for trophic interactions in coastal environments.

\section{MATERIALS AND METHODS}

\section{Prey value estimation}

To estimate prey species-specific energetic values for cod, we used published functional response parameters (Table 1) for each prey species, obtained from experiments in the 3 habitat types (Persson et al. 2012). The consumption rate, $C\left(\mathrm{~J} \mathrm{~s}^{-1}\right)$ when foraging on a single prey type was calculated using the Type II functional response (Holling 1959):

$$
C=\frac{a N}{1+a h N}
$$

Table 1. Functional response parameter values (from Persson et al. 2012), attack rate (a) and handling time (h), for juvenile cod Gadus morhua foraging on grass shrimp Palaemon elegans and brown shrimp Crangon crangon separately in 3 experimental habitat types: bladderwrack Fucus vesiculosus, artificial eelgrass, and sand

\begin{tabular}{|lcc|}
\hline $\begin{array}{l}\text { Habitat and } \\
\text { prey type }\end{array}$ & $\begin{array}{c}\text { Attack rate, } \\
a\left(\mathrm{~m}^{2} \mathrm{~s}^{-1}\right)\end{array}$ & $\begin{array}{c}\text { Handling time, } \\
h\left(\mathrm{~s} \mathrm{~J}^{-1}\right)\end{array}$ \\
\hline $\begin{array}{l}\text { F. vesiculosis } \\
\text { Grass shrimp }\end{array}$ & $1.1 \times 10^{-4}$ & 0.041 \\
$\begin{array}{l}\text { Brown shrimp } \\
\text { Eelgrass }\end{array}$ & $1.2 \times 10^{-4}$ & 0.019 \\
Grass shrimp & $2.4 \times 10^{-4}$ & \\
Brown shrimp & $8.6 \times 10^{-5}$ & 0.045 \\
Sand & $2.1 \times 10^{-3}$ & 0.038 \\
$\begin{array}{l}\text { Grass shrimp } \\
\text { Brown shrimp }\end{array}$ & $1.8 \times 10^{-4}$ & 0.033 \\
\hline
\end{tabular}

where $a$ is the attack rate $\left(\mathrm{m}^{2} \mathrm{~s}^{-1}\right), h$ is the handling time $\left(\mathrm{s} \mathrm{J}^{-1}\right)$ and $N$ is the initial prey density $\left(\mathrm{J} \mathrm{m}^{-2}\right)$. Traditionally, the prey value of a prey type is estimated from the ratio between the energetic value and the handling time of that prey type (Stephens \& Krebs 1986). Since prey density is expressed as energetic density, the parameter $h$ is time per energy unit of that prey type. Hence, species-specific prey values were simply calculated as $h^{-1}$. Energetic content was estimated to be 1898 and $1824 \mathrm{~J}_{\text {ind. }}{ }^{-1}$ for grass shrimp and brown shrimp, respectively, by using published data on energetic content (Szaniawska 1984, Bascinar et al. 2002, Hufnagl 2009).

\section{Predicted switch in foraging strategies}

Juvenile cod may have different foraging strategies in an environment where 2 prey resources occur: a specialist strategy where they feed solely on one of the prey resources or a generalist strategy expressed by a mixed diet where each prey is consumed according to encounter. The predicted habitat-specific consumption rate on a single prey resource was calculated from Eq. (1). whereas the rate for multiple prey resources, $C_{\mathrm{m}}$, was calculated using Eq. (2) in accordance with Persson \& Brönmark (2008) and using the parameter values in Table 1:

$$
C_{\mathrm{m}}=\frac{\sum_{i=1}^{k} a_{i} N_{i}}{1+\sum_{i=1}^{k} a_{i} h_{i} N_{i}} \quad i=1,2 \ldots k
$$

where $k$ is the total number of prey species (represented by brown shrimp and grass shrimp). A switch in foraging strategy is predicted to occur at prey density $N_{\mathrm{s}}$, at which the consumption rate is equal for a generalist strategy and a specialist strategy on the most profitable prey type (prey type 1). Habitat-specific $N_{\mathrm{s}}$ values were calculated using Eq. (3) (Fryxell \& Lundberg 1997):

$$
N_{\mathrm{s}}=\frac{1}{a_{1}\left(h_{2}-h_{1}\right)}
$$

\section{Prey selectivity experiment}

By using high but naturally occurring prey densities, an experiment was set up to test for selectivity between the 2 prey species, depending on habitat type and light level. According to the $N_{\mathrm{s}}$ limits obtained in Eq. (3), the prey densities used in our 
experiments should not induce a specialist diet in juvenile cod. Prey preference was evaluated with the Manly-Chesson (Manly 1974, Chesson 1983) preference index $(\alpha)$ :

$$
\alpha_{i}=\frac{\ln \left(\frac{n_{i 0}-r_{i}}{n_{i 0}}\right)}{\sum_{i=1}^{k} \ln \left(\frac{n_{i 0}-r_{i}}{n_{i 0}}\right)} \quad i=1,2 \ldots k
$$

where $r_{i}$ is the amount of prey type $i$ eaten and $n_{i 0}$ is the initial amount of individuals of prey species $i$. The index ranges from 0 to 1 , where 0 is total avoidance and 1 is total preference for a prey type.

As encounter rate $(a N)$ for a certain prey is habitatspecific and density-dependent, we used speciesbased attack rates and prey densities to calculate a predicted habitat-specific null hypothesis $\left(\alpha_{0}\right)$ for prey preference:

$$
\alpha_{0 i}=\frac{a_{i} N_{i}}{\sum_{i=1}^{k} a_{i} N_{i}} \quad i=1,2 \ldots k
$$

where $\alpha_{0}$ is the predicted preference, and $a_{i}$ is the attack rate and $N_{i}$ is the density of prey type $i$ (brown shrimp or grass shrimp). Hence, the predicted preference for prey type $i$ is the expected proportion of that prey type in the diet if all prey are consumed as encountered. Note that this proportion is different from the proportion of prey type $i$ in the environment whenever attack parameter $a_{i}$ is different from that for alternative prey types.

\section{Experimental animals}

Juvenile (age 1+) Atlantic cod (mean \pm SD $=177 \pm$ $9.0 \mathrm{~mm} \mathrm{TL}, \mathrm{n}=8$ ) were caught using fyke nets in Öresund $\left(55^{\circ} 56^{\prime} \mathrm{N}, 12^{\circ} 46^{\prime} \mathrm{E}\right)$ south of Helsingborg, Sweden, in March 2009. All habitat types used in the experiments were present in the capture area. The fish were collected at depths from 2 to $5 \mathrm{~m}$, where salinity fluctuates between 10 and $15 \%$, and directly transported to an indoor recirculating tank system at Lund University, Sweden. The cod were fed a mixture of live grass shrimp, brown shrimp and frozen northern prawn Pandalus borealis. Live shrimp, used for both feeding and experiments, were collected in shallow water $(<1.0 \mathrm{~m})$ in the same area as the cod, using a large-meshed (1 $\mathrm{mm})$ dip net. In the laboratory, shrimp were selected for the size classes to be used in experiments and held in 501 aerated tanks under the same temperature, salinity and light conditions as the cod.

\section{Experimental protocol}

Experiments were run in eight $1501(0.950 \times$ $0.405 \times 0.400 \mathrm{~m}$, water depth $0.37 \mathrm{~m}$ ) experimental tanks with recirculating water, each tank holding 1 cod. Each fish was held in the same tank throughout the experimental period. Tank sides were shielded with black plastic to avoid visual influences from neighbouring fish. Temperature was $7.4 \pm 0.8^{\circ} \mathrm{C}$, salinity was $15 \%$, and light was kept at a $12: 12 \mathrm{~h}$ light:dark regime with a light level of $0.73 \mu \mathrm{E} \mathrm{m} \mathrm{m}^{-2} \mathrm{~s}^{-1}$ at the water surface. The bottom of each aquarium was covered with a $15 \mathrm{~mm}$ layer of sand filtered through a $1 \mathrm{~mm}$ sieve. Along with this open sand habitat, artificial eelgrass and bladderwrack Fucus vesiculosus were used as habitat treatments in the experiments. Natural bladderwrack attached to stones was collected from a nearshore area $\left(56^{\circ} 40^{\prime} \mathrm{N}\right.$, $\left.12^{\circ} 39^{\prime} \mathrm{E}\right)$ the day before use in the trials. The bladderwrack and stones were backwashed prior to experimental use to prevent additional prey resources from the natural environment entering the experimental tanks. A total of 5 to 6 stones (total volume approximately 3 l), each holding one bladderwrack plant, were used within each experiment. The total volume of bladderwrack vegetation was $1.34 \pm 3.21$ (mean $\pm \mathrm{SD}$ ) with a canopy covering the whole tank area. Eelgrass was mimicked using strands of $5 \mathrm{~mm}$ (width) green curling ribbon, randomly attached to plastic discs at a density of 514 shoots per $\mathrm{m}^{-2}$. Each shoot consisted of 3 ribbons, with a 'shoot' length of $320 \pm 20 \mathrm{~mm}$. Eelgrass density was based on survey data from Öresund (Olsson 2005).

In total, 40 prey consisting of 20 brown shrimp (mean $\pm \mathrm{SD}=38.5 \pm 5.0 \mathrm{~mm}$ TL) and 20 grass shrimp $(36.2 \pm 4.9 \mathrm{~mm} \mathrm{TL})$, were used in each selectivity trial. The energetic value for 20 shrimp recalculated to the amount of energy per $\mathrm{m}^{2}$ was $98.6 \mathrm{~kJ} \mathrm{~m}^{-2}$ for brown shrimp and $103 \mathrm{~kJ} \mathrm{~m}^{-2}$ for grass shrimp. Initial prey densities are shown in Fig. 1 to allow for comparison with curve fitting and habitat-specific $N_{\mathrm{s}}$ values. Experiments were run in the 3 different habitats (bladderwrack, artificial eelgrass, sand) and 2 light regimes

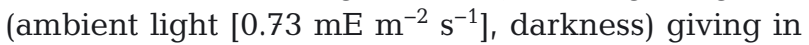
total, 6 treatment combinations. Each trial was initiated by shutting off water circulation to prevent chemical cues from spreading between tanks. Prey were collected and poured into the tank, marking the start of the experiment. Trials were run for $2 \mathrm{~h}$ and ended by dip-netting the cod out of the aquarium and into a separate aerated container. Vegetation was removed and backwashed to collect prey from vegetation. Remaining prey were dip-netted out of the tanks 
using a hand dip-net (1 mm mesh size), and the numbers of surviving prey in each aquarium were recorded. The tank was considered emptied of prey when no shrimp were caught in 5 subsequent dip-nettings. The 5 nettings were established as a sufficient number from a control treatment in which 20 individuals $\left(54\right.$ ind. $\mathrm{m}^{-2}$ ) of each prey type were transferred to experimental tanks, where they were acclimatised for $2 \mathrm{~h}$. The retrieval after 5 empty nettings was $100 \%$ for brown shrimp and $99.4 \%$ for grass shrimp. After retrieving the prey in the main treatments, each aquarium was prepared for the next trial by changing substrate, turning on the water circulation and transferring the cod back into the aquarium.

Experimentally obtained preference $(\alpha)$ was tested against the null hypotheses of no preference $\left(\alpha_{0}\right)$ using 1-sample $t$-tests on data from one of the prey categories (grass shrimp), to avoid the obvious autocorrelation in preference indices between prey species within trials. A randomized block (rb) ANOVA was used to test for differences in prey preference between habitat types and light levels, using $\alpha$ for grass shrimp as the dependent variable. Each individual cod participated in all treatment combinations, and individual identities were included as a blocking factor in the statistical model to compensate for the degrees of freedom in the experimental design (Quinn \& Keough 2002). Treatment order was randomized for cod individuals to minimise the effects of time in the experiment. Trials were run every second day to allow the cod to acclimatise and fully digest the prey between runs. A post-hoc Tukey's test was used to evaluate the within-subject effect of habitat treatments. Statistical analyses were carried out using R software for Macintosh.

\section{RESULTS}

Predicted habitat-specific and prey-dependent capture rates, $C$, are presented in Fig. 1. Calculations of prey value $\left(h^{-1}\right)$ revealed that brown shrimp were energetically more profitable than grass shrimp in all habitat types: sand $38.5>30.3$, eelgrass $26.3>22.2$, and bladderwrack $52.6>24.4 \mathrm{~J} \mathrm{~s}^{-1}$ for brown shrimp and grass shrimp, respectively.

Determination of optimal foraging strategies showed that individual juvenile cod should feed as generalists in all 3 habitat types and switch to a specialist diet consisting of brown shrimp only when prey densities are high (Fig. 1). Calculated habitatspecific $N_{\mathrm{s}}$ indicated switches to occur in bladderwrack at $410 \mathrm{~kJ} \mathrm{~m}^{-2}$, sand at $794 \mathrm{~kJ} \mathrm{~m}^{-2}$, and eelgrass
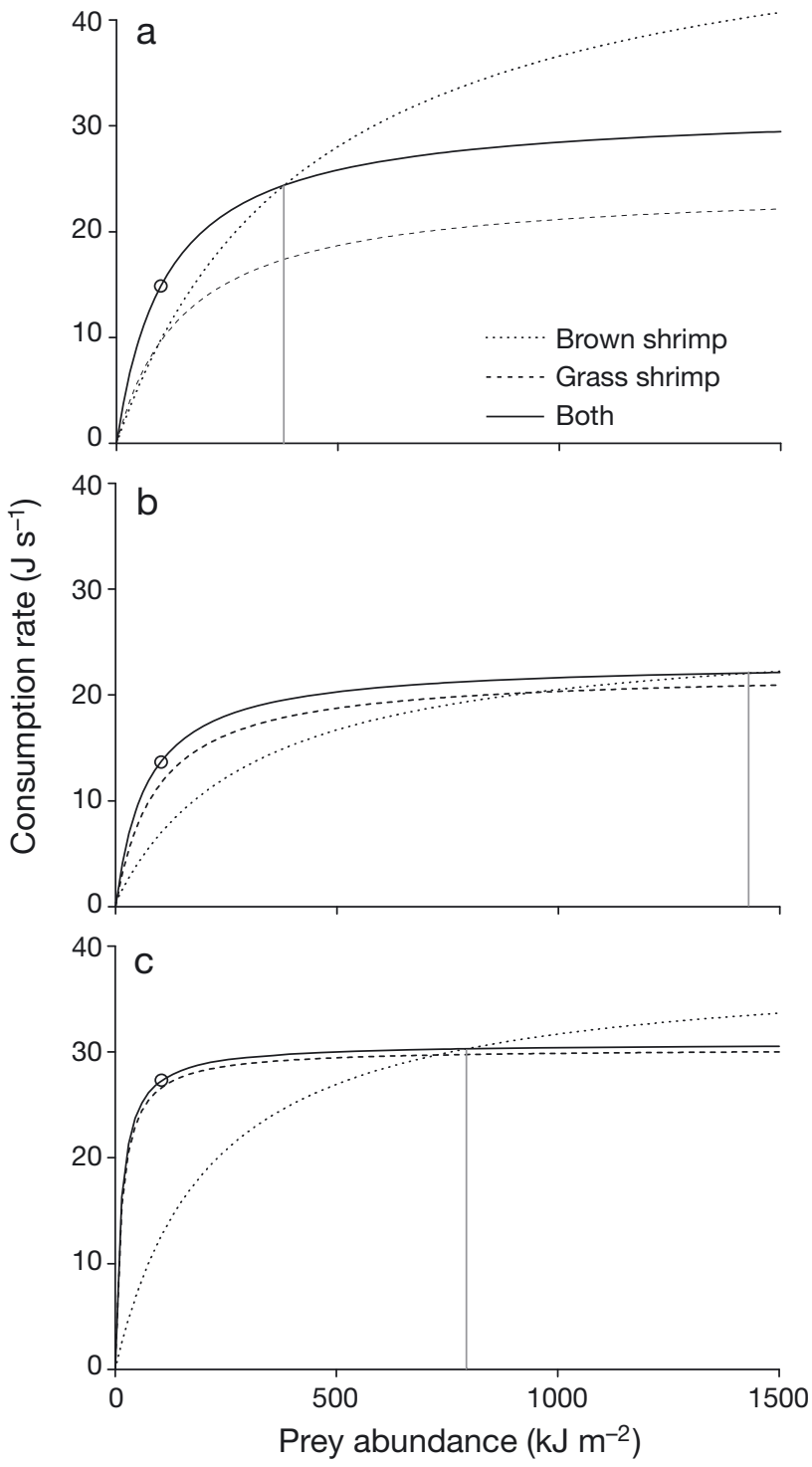

Fig. 1. Predicted consumption rate of juvenile cod Gadus morhua foraging on brown shrimp Crangon crangon and grass shrimp Palaemon elegans in 3 experimental habitats: (a) bladderwrack Fucus vesiculosus (b) artificial eelgrass, (c) sand. Predictions were calculated using attack rate and handling time parameters from Persson et al. (2012). Solid curve: predicted juvenile cod consumption when foraging on simultaneously available brown shrimp and grass shrimp. Grey vertical lines: predicted prey density for the switch from generalist to specialist diets in each habitat. Circles: initial prey density for selection experiments (see Fig. 2)

at $1430 \mathrm{~kJ} \mathrm{~m}^{-2}$. These energy values correspond to numerical values of approximately 435, 225 and 785 brown shrimp $\mathrm{m}^{-2}$ in bladderwrack, sand and eelgrass respectively, indicating a predicted switch in foraging strategy to occur at prey densities much higher than those used in the prey-choice experiments or those found in nature (Table 2). 
Table 2. Grass shrimp Palaemon elegans and brown shrimp Crangon crangon. Natural density (ind. $\mathrm{m}^{-2}$ ) and density converted to energetic value $\left(\mathrm{J} \mathrm{m}^{-2}\right)$ of grass shrimp and brown shrimp, in 3 different habitat types: bladderwrack Fucus vesiculosus, eelgrass Zostera marina, and sand. Data synthesised from Pihl \& Rosenberg (1982), Baden \& Pihl (1984), Lapinska \& Szaniawska (2006), Wikstrom \& Kautsky (2007), Jephson et al. (2008), Persson et al. (2008) and Persson et al. (2012). 'Predicted switch' indicates the prey abundance and equivalent energetic value (J) at which juvenile cod Gadus morhua should switch from generalist to specialist feeding

\begin{tabular}{|c|c|c|c|c|c|c|}
\hline \multirow[t]{2}{*}{ Habitat } & \multicolumn{2}{|c|}{ Grass shrimp } & \multicolumn{2}{|c|}{ Brown shrimp } & \multicolumn{2}{|c|}{ Predicted switch } \\
\hline & 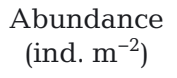 & $\begin{array}{c}\text { Energetic } \\
\text { value }\left(\mathrm{J} \mathrm{m}^{-2}\right)\end{array}$ & $\begin{array}{l}\text { Abundance } \\
\text { (ind. } \mathrm{m}^{-2} \text { ) }\end{array}$ & $\begin{array}{c}\text { Energetic } \\
\text { value }\left(\mathrm{J} \mathrm{m}^{-2}\right)\end{array}$ & $\begin{array}{l}\text { Abundance } \\
\text { (ind. } \mathrm{m}^{-2} \text { ) }\end{array}$ & $\begin{array}{c}\text { Energetic } \\
\text { value }\left(\mathrm{J} \mathrm{m}^{-2}\right)\end{array}$ \\
\hline Bladderwrack & $0-42$ & $0-79700$ & $0-14$ & $0-25500$ & 225 & 410000 \\
\hline Eelgrass & $0-46$ & $0-87300$ & $0-7$ & $0-12800$ & 785 & 1430000 \\
\hline Sand & $0-3$ & $0-5700$ & $2-100$ & 3650-182000 & 435 & 794000 \\
\hline
\end{tabular}

The rb ANOVA revealed a difference in selectivity for grass shrimp between habitats $\left(F_{2,35}=14.622, \mathrm{p}<\right.$ 0.001). Tukey's tests showed significant differences in selectivity for all habitat comparisons: bladderwrack and eelgrass $(p=0.038)$, bladderwrack and sand $(p<0.001)$ and eelgrass and sand $(p=0.020)$, where selectivity for grass shrimp was lowest in bladderwrack and highest in sand (Fig. 2). The effects of individual fish were marginally insignificant $\left(F_{7,35}=\right.$ $2.238, \mathrm{p}=0.054$ ), whereas the effects of light regime and the interaction between habitat and light were not significant $\left(F_{1,35}=0.643, \mathrm{p}=0.428\right.$ and $F_{2,35}=$ $0.793, p=0.460$, respectively), indicating that functional response parameters, estimated in light condi-

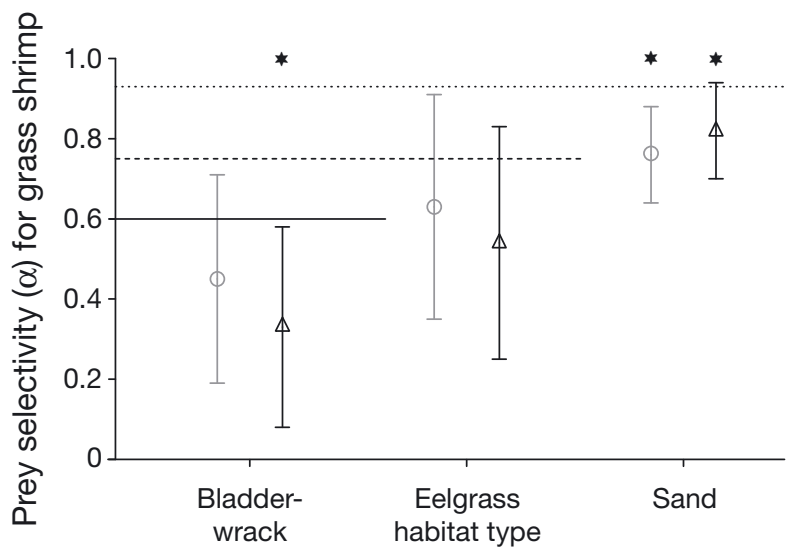

Fig. 2. Prey selectivity (Manly-Chesson $[\alpha]$ ) for juvenile cod Gadus morhua feeding on grass shrimp Palaemon elegans versus brown shrimp Crangon crangon in 3 experimental habitat types in light $(0)$ and dark $(\Delta)$ conditions. Horizontal lines: predicted selectivity for grass shrimp, 0.93 in sand, 0.75 in eelgrass and 0.60 in bladderwrack, which together with predictions for brown shrimp, total 1. Experimentally established values were in bladderwrack ( - ) light 0.45 and dark 0.33, artificial eelgrass (---) light 0.63 and dark 0.54 and sand $(\cdots)$ light 0.76 and dark 0.83 . Vertical error bars $=$ SD. ${ }^{*}$ Established prediction is significantly different from that predicted tions, were valid also in dark conditions. Residuals did not differ from normal distribution (KolmogorovSmirnov $Z=0.102, \mathrm{p}=0.662)$.

Predicted cod preferences $\left(\alpha_{0}\right)$ for grass shrimp along with experimentally established values are presented in Fig. 2. The 1-sample $t$-tests revealed that grass shrimp were eaten in significantly lower proportions than expected in $\operatorname{sand}_{\text {Light }}\left(t_{7}=-3.937, \mathrm{p}=\right.$ $0.006)$, sand Dark $\left(t_{7}=-2.489, \mathrm{p}=0.042\right)$ and bladderwrack $_{\text {Dark }}\left(t_{7}=-2.990, \mathrm{p}=0.020\right)$, whereas prey was eaten in proportions not different from predicted values in eelgrass Light $_{\left(t_{7}=-1.251, p=0.251\right) \text {, eelgrass }}$ Dark $\left(t_{7}=-2.140, \mathrm{p}=0.070\right)$ and bladderwrack $\mathrm{Light}_{\text {t }}\left(t_{7}=\right.$ $-1.668, \mathrm{p}=0.139$ ).

\section{DISCUSSION}

Optimal foraging theory predicts that foragers should choose food that maximises energy intake per unit time (Macarthur \& Pianka 1966, Stephens \& Krebs 1986). Because the mean energetic value of the 2 shrimp species is almost identical, handling time is the critical factor determining prey value. This was higher for brown shrimp than for grass shrimp in all habitat types and, thus, juvenile cod should prefer brown shrimp. However, a predator should include additional prey in the diet and forage as a generalist if the density of the most profitable prey is below a certain threshold (Heller 1980, Holt \& Kotler 1987, Brown \& Mitchell 1989, Sih \& Christensen 2001). Using estimated habitat and prey type dependent parameters for attack rate and handling time, we predicted this threshold ( $N_{\mathrm{s}}$ in Eq. 3) to occur at high prey densities. From a literature survey on brown shrimp and grass shrimp densities found in natural systems (Table 2), we concluded that juvenile cod should feed as generalists under natural conditions independently of habitat type, as densities always 
fall below the threshold predicting a specialist strategy (Table 2, Fig. 1).

Predators may also display prey selectivity even if they are generalists (Turesson et al. 2002, Persson \& Brönmark 2008). Since the attack rates for our 2 prey types are different (Table 1), cod may encounter the 2 prey types at different rates when prey densities are similar, generating selectivity without involving active choice by the predator (Johansson et al. 2004, Persson \& Brönmark 2008). Prey-dependent attack rates (Table 1) would thus result in grass shrimp being encountered more frequently than brown shrimp, and the prediction of a higher inclusion of grass shrimp in the diet of cod at low prey densities, especially in the sand habitat (Fig. 1). This, in combination with the anti-predatory dependence of grass shrimp on vegetation, predicts high relative predation rates on grass shrimp in sand habitats for all prey densities, as shown in Fig. 2. In an environment where vegetation is deteriorated by eutrophication, grass shrimp would gradually lose their preferred habitat and their main defence against cod predation, and thus the relative predation rates on grass shrimp initially should increase. Juvenile cod also forage in vegetated habitats, and grass shrimp aggregating in the remaining vegetation would produce high local grass shrimp densities and presumably a profitable foraging habitat for the cod. This may result in an overall increase in predation pressure on grass shrimp until a new equilibrium state is reached, at which cod, due to prey suppression, may switch either their preferred prey or habitat.

In 3 of the diet-choice experiments, cod selected prey according to the predictions based on encounter rates. However, in the remaining 3 treatments, cod showed a lower than predicted consumption of grass shrimp (Fig. 2). Although being well below the threshold for a specialist strategy $\left(N_{\mathrm{s}}\right.$, Fig. 1$)$, prey densities were in the higher ranges of naturally occurring densities. High prey densities may incur simultaneous encounters with the 2 prey species, when the predator must choose which prey item to attack. As brown shrimp have a slightly higher prey value than grass shrimp, cod should logically select brown shrimp before grass shrimp upon a simultaneous encounter. Simultaneous encounters with both prey types can thus partly explain the lower than predicted selectivity for grass shrimp in the sand habitat. An alternative explanation could be related to prey depletion over the time of the experiment. The high predicted and measured selectivity for grass shrimp in the sand habitat could lead to decreasing probabilities for encounters with grass shrimp with increasing number of predation events. This is less likely to be the case, however, as cod ate a maximum of 11 grass shrimp during a trial. Prey depletion is even less likely to explain the lower than predicted selectivity of grass shrimp in bladderwrack at night, as both the predicted and observed selectivities were lower than those for sand. We suggest this result originates from the nocturnal activity of brown shrimp in a non-preferred habitat.

The decrease in complexity due to habitat loss from eutrophication may affect interactions between organisms. There is currently limited mechanistic understanding of predator-prey interactions and the effects of habitat degradation in coastal environments. Our results imply that if environments are subjected to a decrease in complexity, e.g. a shift towards a higher number of sandy habitats, grass shrimp should experience a relative increase in mortality risk compared to brown shrimp, despite the fact that brown shrimp provide a higher prey value to cod. Grass shrimp is identified as a key component for algal blooms in coastal environments through its predation on the grazer community, decreasing grazer densities and thus facilitating the overgrowth of epiphytic algae on macrovegetation (Moksnes et al. 2008, Andersson et al. 2009). In systems where processes are governed by the interactions between mesopredators and mesograzers (Eriksson et al. 2009, Baden et al. 2010), grass shrimp contribute to decreased habitat complexity by creating conditions that favour filamentous algae over macrovegetation. Considering this trophic effect, we suggest that juvenile cod may partly reduce the negative effects of eutrophication on macrovegetation, suppressing grass shrimp to a higher extent in less complex environments. However, to obtain a complete understanding of the trophic effects of cod predation, other members of the system, such as crabs and small fish, need to be considered simultaneously. Overall, our study illustrates the complex outcomes that may be generated even with only a few interacting species in communities, highlighting the challenges of managing such systems, but also the importance of a full mechanistic understanding of interaction strengths.

Acknowledgements. Financial support was provided by the Swedish Research Council for Environment, Agricultural Sciences and Spatial Planning (FORMAS) to A.P. and A.N., the Krapperup Foundation to A.P., and the Oscar and Lili Lamm Memorial Foundation to A.P. All work was conducted in accordance with ethical laws of Sweden and permission from the Swedish Board of Agriculture and the Swedish Board of Fisheries. 


\section{LITERATURE CITED}

Anderson TW (2001) Predator responses, prey refuges, and density-dependent mortality of a marine fish. Ecology 82 : 245-257

Andersson S, Persson M, Moksnes PO, Baden S (2009) The role of the amphipod Gammarus locusta as a grazer on macroalgae in Swedish seagrass meadows. Mar Biol 156: 969-981

Baden SP, Pihl L (1984) Abundance, biomass and production of mobile epibenthic fauna in Zostera marina (L.) meadows, western Sweden. Ophelia 23:65-90

> Baden S, Gullstrom M, Lunden B, Pihl L, Rosenberg R (2003) Vanishing seagrass (Zostera marina, L.) in Swedish coastal waters. Ambio 32:374-377

- Baden S, Bostrom C, Tobiasson S, Arponen H, Moksnes PO (2010) Relative importance of trophic interactions and nutrient enrichment in seagrass ecosystems: a broadscale field experiment in the Baltic-Skagerrak area. Limnol Oceanogr 55:1435-1448

Baden S, Emanuelsson A, Pihl L, Svensson CJ, Aberg P (2012) Shift in seagrass food web structure over decades is linked to overfishing. Mar Ecol Prog Ser 451:61-73

Bascinar NS, Düzgünes E, Bascinar N, Saglam AE (2002) A preliminary study on reproductive biology of Palaemon elegans Rathke, 1837 along the south-eastern Black Sea coast. Turk J Fish Aquat Sci 2:109-116

> Beck MW, Heck KL, Able KW, Childers DL and others (2001) The identification, conservation, and management of estuarine and marine nurseries for fish and invertebrates. Bioscience 51:633-641

Berglund A (1980) Niche differentiation between two littoral prawns in Gullmar Fjord, Sweden-Palaemon adspersus and Palaemon squilla. Holarct Ecol 3:111-115

Borg A, Pihl L, Wennhage H (1997) Habitat choice by juvenile cod (Gadus morhua L.) on sandy soft bottoms with different vegetation types. Helgol Meersunters 51: 197-212

Brown JS, Mitchell WA (1989) Diet selection on depletable resources. Oikos 54:33-43

- Carr MH (1989) Effects of macroalgal assemblages on the recruitment of temperate zone reef fishes. J Exp Mar Biol Ecol 126:59-76

Casini M, Hjelm J, Molinero JC, Lovgren J and others (2009) Trophic cascades promote threshold-like shifts in pelagic marine ecosystems. Proc Natl Acad Sci USA 106:197-202

Chesson J (1983) The estimation and analysis of preference and its relationship to foraging models. Ecology 64: 1297-1304

> Cloern JE (2001) Our evolving conceptual model of the coastal eutrophication problem. Mar Ecol Prog Ser 210: 223-253

> Cote D, Moulton S, Scruton DA, McKinley RS (2001) Microhabitat use of juvenile Atlantic cod in a coastal area of Bonavista Bay, Newfoundland. Trans Am Fish Soc 130: 1217-1223

> Daskalov GM, Grishin AN, Rodionov S, Mihneva V (2007) Trophic cascades triggered by overfishing reveal possible mechanisms of ecosystem regime shifts. Proc Natl Acad Sci USA 104:10518-10523

> Diehl S (1988) Foraging efficiency of three freshwater fishes: effects of structural complexity and light. Oikos 53: 207-214

Eriksson BK, Ljunggren L, Sandstrom A, Johansson G and others (2009) Declines in predatory fish promote bloom- forming macroalgae. Ecol Appl 19:1975-1988

> Frank KT, Petrie B, Choi JS, Leggett WC (2005) Trophic cascades in a formerly cod-dominated ecosystem. Science 308:1621-1623

Fryxell JM, Lundberg P (1998) Individual behavior and community dynamics. Population and community biology series 20. Chapman \& Hall, London

- Gibson RN (1994) Impact of habitat quality and quantity on the recruitment of juvenile flatfishes. Neth J Sea Res 32: 191-206

Gotceitas V, Colgan P (1989) Predator foraging success and habitat complexity: quantitative test of the threshold hypothesis. Oecologia 80:158-166

Gotceitas V, Fraser S, Brown JA (1995) Habitat use by juvenile Atlantic cod (Gadus morhua) in the presence of an actively foraging and non-foraging predator. Mar Biol 123:421-430

- Gotceitas V, Fraser S, Brown JA (1997) Use of eelgrass beds (Zostera marina) by juvenile Atlantic cod (Gadus morhua). Can J Fish Aquat Sci 54:1306-1319

Halpern BS, Walbridge S, Selkoe KA, Kappel CV and others (2008) A global map of human impact on marine ecosystems. Science 319:948-952

Heck KL, Valentine JF (2007) The primacy of top-down effects in shallow benthic ecosystems. Estuaries Coasts 30:371-381

> Heller R (1980) On optimal diet in a patchy environment. Theor Popul Biol 17:201-214

Holling CS (1959) Some characteristics of simple types of predation and parasitism. Can Entomol 91:385-398

> Holt RD, Kotler BP (1987) Short-term apparent competition. Am Nat 130:412-430

Hufnagl M (2009) Population dynamics and lifecycle of the brown shrimp Crangon crangon (Caridea, L. 1758). Experimental, biochemical and theoretical aspects. PhD dissertation, University of Hamburg

- Hutchings JA, Myers RA (1994) What can be learned from the collapse of a renewable resource? Atlantic cod, Gadus morhua, of Newfoundland and Labrador. Can J Fish Aquat Sci 51:2126-2146

Isaksson I, Pihl L, Vanmontfrans J (1994) Eutrophicationrelated changes in macrovegetation and foraging of young cod (Gadus morhua): a mesocosm experiment. J Exp Mar Biol Ecol 177:203-217

> Jackson JBC, Kirby MX, Berger WH, Bjorndal KA and others (2001) Historical overfishing and the recent collapse of coastal ecosystems. Science 293:629-638

> Jephson T, Nystrom P, Moksnes PO, Baden SP (2008) Trophic interactions in Zostera marina beds along the Swedish coast. Mar Ecol Prog Ser 369:63-76

Johansson J, Turesson H, Persson A (2004) Active selection for large guppies, Poecilia reticulata, by the pike cichlid, Crenicichla saxatilis. Oikos 105:595-605

Keats DW, Steele DH, South GR (1987) The role of fleshy macroalgae in the ecology of juvenile cod (Gadus morhua L.) in inshore waters off eastern Newfoundland. Can J Zool 65:49-53

Kuipers BR, Dapper R (1981) Production of Crangon crangon in the tidal zone of the Dutch Wadden Sea. Neth J Sea Res 15:33-53

> Lapinska E, Szaniawska A (2006) Environmental preferences of Crangon crangon (Linnaeus, 1758), Palaemon adspersus Rathke, 1837, and Palaemon elegans Rathke, 1837 in the littoral zone of the Gulf of Gdansk. Crustaceana 79:649-662 
Laurel BJ, Gregory RS, Brown JA (2003) Predator distribution and habitat patch area determine predation rates on age-0 juvenile cod Gadus spp. Mar Ecol Prog Ser 251: 245-254

Macarthur RH, Pianka ER (1966) On optimal use of a patchy environment. Am Nat 100:603-609

Manly BFJ (1974) A model for certain types of selection experiments. Biometrics 30:281-294

Moksnes PO, Gullstrom M, Tryman K, Baden S (2008) Trophic cascades in a temperate seagrass community. Oikos 117:763-777

Olsson P (2005) Marine field studies in Öresund 2005 - Eelgrass. Toxicon, Landskrona (in Swedish)

Orth RJ, Heck KL, Vanmontfrans J (1984) Faunal communities in seagrass beds: a review of the influence of plant structure and prey characteristics on predator-prey relationships. Estuaries 7:339-350

Orth RJ, Carruthers TJB, Dennison WC, Duarte CM and others (2006) A global crisis for seagrass ecosystems. Bioscience 56:987-996

Osterblom H, Hansson S, Larsson U, Hjerne O, Wulff F, Elmgren R, Folke C (2007) Human-induced trophic cascades and ecological regime shifts in the Baltic Sea. Ecosystems 10:877-889

Pauly D, Christensen V, Guenette S, Pitcher TJ and others (2002) Towards sustainability in world fisheries. Nature 418:689-695

> Persson A, Brönmark C (2008) Pikeperch Sander lucioperca trapped between niches: foraging performance and prey selection in a piscivore on a planktivore diet. J Fish Biol 73:793-808

> Persson M, Andersson S, Baden S, Moksnes PO (2008) Trophic role of the omnivorous grass shrimp Palaemon elegans in a Swedish eelgrass system. Mar Ecol Prog Ser 371:203-212

Persson A, Ljungberg P, Andersson M, Götzman E, Anders Nilsson PA (2012) Foraging performance of juvenile Atlantic cod (Gadus morhua) and profitability of coastal habitats. Mar Ecol Prog Ser 456:245-253

Petersen CGJ (1918) The sea bottom and its production of fish food. Report of the Danish Biological Station 25:1-62

Pihl L (1982) Food intake of young cod (Gadus morhua) and flounder (Platichthys flesus) in a shallow bay on the Swedish west coast. Neth J Sea Res 15:419-432

Pihl L, Rosenberg R (1982) Production, abundance, and bio-

Editorial responsibility: Kenneth Heck Jr., Dauphin Island, Alabama, USA mass of mobile epibenthic marine fauna in shallow waters, western Sweden. J Exp Mar Biol Ecol 57:273-301

Quinn GP, Keough MJ (2002) Experimental design and data analysis for biologists. Cambridge University Press, Cambridge

Richardson AJ, Bakun A, Hays GC, Gibbons MJ (2009) The jellyfish joyride: causes, consequences and management responses to a more gelatinous future. Trends Ecol Evol 24:312-322

Rönnbäck P, Kautsky N, Pihl L, Troell M, Soerqvist T, Wennhage $H$ (2007) Ecosystem goods and services from Swedish coastal habitats: identification, valuation, and implications of ecosystem shifts. Ambio 36:534-544

Savino JF, Stein RA (1982) Predator-prey interaction between largemouth bass and bluegills as influenced by simulated, submersed vegetation. Trans Am Fish Soc 111:255-266

Short FT, Wyllie-Echeverria S (1996) Natural and humaninduced disturbance of seagrasses. Environ Conserv 23: $17-27$

Sih A, Christensen B (2001) Optimal diet theory: When does it work, and when and why does it fail? Anim Behav 61: 379-390

Smith BE, Ligenza TJ, Almeida FP, Link JS (2007) The trophic ecology of Atlantic cod: insights from tri-monthly, localized scales of sampling. J Fish Biol 71:749-762

Stephens DW, Krebs JR (1986) Foraging theory. Monographs in behavior and ecology. Princeton University Press, Princeton, NJ

Szaniawska A (1984) Seasonal changes in weight and energy content in the Crangon crangon population of Gdansk Bay. Ophelia Suppl 3:247-251

Tupper M, Boutilier RG (1995) Effects of habitat on settlement, growth, and post-settlement survival of Atlantic cod (Gadus morhua). Can J Fish Aquat Sci 52:1834-1841

Turesson H, Persson A, Brönmark C (2002) Prey size selection in piscivorous pikeperch (Stizostedion lucioperca) includes active prey choice. Ecol Freshw Fish 11:223-233

Vogt H, Schramm W (1991) Conspicuous decline of Fucus in Kiel Bay (Western Baltic): What are the causes? Mar Ecol Prog Ser 69:189-194

Wikstrom SA, Kautsky L (2007) Structure and diversity of invertebrate communities in the presence and absence of canopy-forming Fucus vesiculosus in the Baltic Sea. Estuar Coast Shelf Sci 72:168-176

Submitted: November 11, 2011; Accepted: July 9, 2012 Proofs received from author(s): October 1, 2012 